\title{
Swarming behaviour and mass occurrences in the world's largest giant pill-millipede species, Zoosphaerium neptunus, on Madagascar and its implication for conservation efforts (Diplopoda: Sphaerotheriida)
}

\author{
Thomas Wesener' and Kai schütte"
}

\author{
Correspondence: \\ Thomas Wesener \\ Field Museum of Natural History, Zoology - Insects \\ 1400 S. Lake Shore Drive, 60605 Chicago, Illinois, U.S.A. \\ E-mail: twesener@uni-bonn.de
}

\begin{abstract}
The first records of mass occurrences (swarming behaviour) in giant pill-millipedes, order sphaerotheriida, are reported from Madagascar. Swarming behaviour in the order Sphaerotheriida seems to be restricted to a single of more than sixty described Malagasy species, Zoosphaerium neptunus (Butler, 1872), which is the world's largest known giant pill-millipede. Rolled-up individuals can be up to the size of a baseball, tennis ball or small orange, but only females reach this giant size, males being smaller than a ping-pong ball. Nine occurrences of such Z. neptunus swarms were analyzed based on actual specimens, video or photographic evidence collected by other researchers, dating back as far as 1892. One additional swarm, comprising several thousand individuals was examined in detail, with 260 randomly collected specimens being dissected and measured. The findings highlight that the swarming behaviour in Z. neptunus differs from that of all other millipedes in two important details: (1) The individual swarm is restricted to specimens of a single related size (and presumably age) class; often only sexually immature individuals; (2) the swarming behaviour is obligate, most, if not all specimens of the species in a given area participate in such swarms; $Z$. neptunus specimens are rarely, if ever, not found in a swarm. Reasons behind such massing events in millipedes are currently little understood, but a potential explanation for the mass occurrences in Z. neptunus might be higher survival rate from predation in combination with a close sibling relationship between members of one swarm. The almost obligate swarming behaviour in the widespread Z. neptunus species might represent a conservation problem, since whole swarms, and therefore a whole generation in a given area, can be lost through anthropogenic interferences such as over-collecting for the pet trade, habitat fragmentation or road kills.
\end{abstract}

\section{RÉSUMÉ}

Il est rare que I'Homme se retrouve au contact des myriapodes et plus rare encore que de cette rencontre naisse un antagonisme. On peut citer le cas du mille-pattes indien
Xenobolus carnifex qui dégrade les toits et celui des essaimages de myriapodes qui entraînent souvent de graves problèmes dont le plus courant est l'invasion de maisons, voire de villages entiers. Ce comportement inhabituel est surtout mentionné pour l'Europe et les raisons de ce grégarisme chez les mille-pattes sont encore peu comprises. Certains pensent que ces rassemblements sont liés à la surpopulation ou qu'ils augmentent l'efficacité des défenses chimiques. Une des rares similitudes entre ces phénomènes est que les spécimens y participant sont adultes ou subadultes, jamais juvéniles.

Cet article fait état de la première observation d'un regroupement en masse (comportement grégaire) chez les grands mille-pattes volveurs, ordre des sphaerotheriida, à Madagascar. Au sein de cet ordre, le comportement grégaire semble se limiter à une seule espèce parmi plus de soixante espèces malgaches connues, Zoosphaerium neptunus (Butler, 1872), actuellement l'espèce la plus grande des millepattes volveurs connus. Enroulés, des spécimens peuvent atteindre la taille d'une balle de base-ball, de tennis, ou d'une petite orange; mais cela ne concerne que les femelles, les mâles étant plus petits qu'une balle de ping-pong. Notre étude se fonde sur l'analyse de neuf cas d'un tel grégarisme chez Z. neptunus, soit à partir d'observations directes, soit à partir de documents, notamment photographiques ou vidéo, recueillis par d'autres chercheurs, et ce aussi loin que 1892. Nous avons examiné en détail un essaim composé de plusieurs milliers de spécimens, dont 260 récoltés au hasard, disséqués et mesurés. Les résultats mettent en évidence que le comportement grégaire de $Z$. neptunus diffère de celui des autres mille-pattes sur deux points importants : (1) chaque essaim ne comporte que des spécimens de taille proche (et probablement d'un âge similaire), souvent exclusivement des spécimens immatures sexuellement; (2) le comportement grégaire est obligatoire ; la plupart, si ce n'est tous les spécimens de l'espèce d'une zone donnée participent à ce genre d'essaimages, - Z. neptunus est rarement, sinon jamais, observé hors d'un essaim. On ignore les causes du grégarisme chez les mille-pattes, mais une explication possible du regroupement en masse chez $Z$. neptunus pourrait être un 
meilleur taux de survie face à la prédation en combinaison avec une relation fraternelle renforcée entre les membres d'un même essaim. Le comportement grégaire quasi-obligatoire chez le très répandu Z. neptunus pourrait compliquer sa préservation du fait que les interférences humaines telles que sa surexploitation à des fins commerciales, la fragmentation de son habitat ou le risque de mourir sur la route peuvent entraîner la perte d'essaims entiers, et donc de toute une génération dans une zone donnée.

KEY-WORDS: Swarming behaviour, millipede, island gigantism. MOTS CLEFS : grégaire, mille-pattes, gigantisme insulaire.

\section{INTRODUCTION}

There are few situations when humans come into contact with millipedes, and even fewer which result in man-millipede conflict. Among the most fascinating are, aside the roof-eating behaviour of the Indian millipede Xenobolus carnifex (Alagesan and Muthukrishnan 2006), millipede swarms. Those millipede swarms are fascinating situations, often resulting in serious problems. The oldest record of such an event is from Theophrastus who reported that a millipede swarm drove the inhabitants of Rhoeteum, a village located in present day Turkey, into the sea (Sharples 1994). Fossil findings of millipede swarms date back to the Upper Carboniferous (Wilson 2006). In present times, the occurrence of swarming millipedes can cause situations as serious as derailed trains (Verhoeff 1900); these events resulted in the common Japanese name 'Train Millipede' for a species involved into such accidents (Niijima 2001). More common are invaded houses (Voigtländer 2005) or whole German villages (Lee 2008). In 2007, a wall had to be built around the German city of Obereichstätt to keep the millipedes out (Enghoff and Kebapci 2008). Most records of this unusual behaviour are from Europe (Ehrnsberger 2002, Voigtländer 2005). The reasons for this swarming behaviour in millipedes are still little understood. One of the few similarities between the events is that participating individuals are adults or sub-adults, never juveniles (with the exception of some juvenile Polydesmida (Lewis 1971), which stay together in a swarm after hatching but don't migrate). In case of the fossil swarming millipedes, it was suggested that agglomeration increases the efficiency of chemical defenses in millipedes (Wilson 2006).

While for numerous millipede orders records of such unusual events exist (summary in Voigtländer 2005), nothing was previously known about swarming in giant pill-millipedes, order Sphaerotheriida, or any other millipede species occurring on Madagascar. The giant pill-millipedes on Madagascar, members of the Malagasy-Indian family Arthrosphaeridae (Wesener and Vandenspiegel 2009), belong because of their island gigantism (Wesener 2009) to the most astonishing invertebrates of the world's third largest island. Some species of the endemic genus Zoosphaerium are much larger than giant pill-millipedes from other areas. Fully grown individuals reach, when rolled-up, the size of a baseball (Wesener and Wägele 2008), while the largest species from South Africa and India only reach the size of a ping-pong ball (Vandenspiegel et al. 2002).

The world's largest described giant pill-millipede species is Zoosphaerium neptunus (Butler 1872), also called 'EmeraldGreen Giant Pill-Millipede' because of its shiny green colour (Figure 1), where adult females can reach a gigantic size of

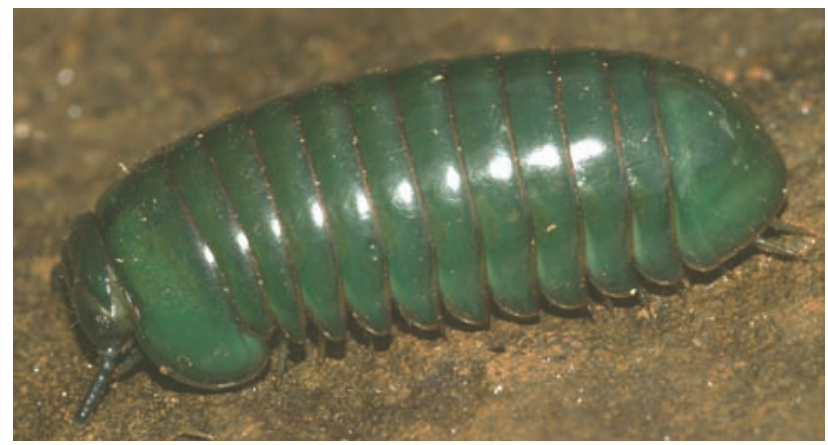

FIGURE 1. The 'Madagascar Green-Emerald Giant Pill-Millipede', Zoosphaerium neptunus (Butler, 1872). Juvenile individual, approximately 30 $\mathrm{mm}$ long, photographed at Andasibe.

$90 \mathrm{~mm}$. Z. neptunus is in many aspects quite an unusual giant pill-millipede species; firstly because the species is one of the few widely distributed on Madagascar (Figure 2), and secondly because the males are much smaller than the females, reaching only up to $45 \mathrm{~mm}$ in length. In fact, because of their size difference, males were even described as a separate species, sphaerotherium digitale (see Wesener and Wägele 2008).

On Madagascar, species of giant pill-millipedes are rarely found in large aggregations. Collectors usually only find as many as five up to ten individuals in the same spot (own experiences). The first report dealing with large aggregations of giant pillmillipedes on Madagascar are more than a century old and came from the English missionary James Sibree. He mentioned in his book (Sibree 1915:159-160, but observation made 1892): "In passing along the forest paths we frequently come across

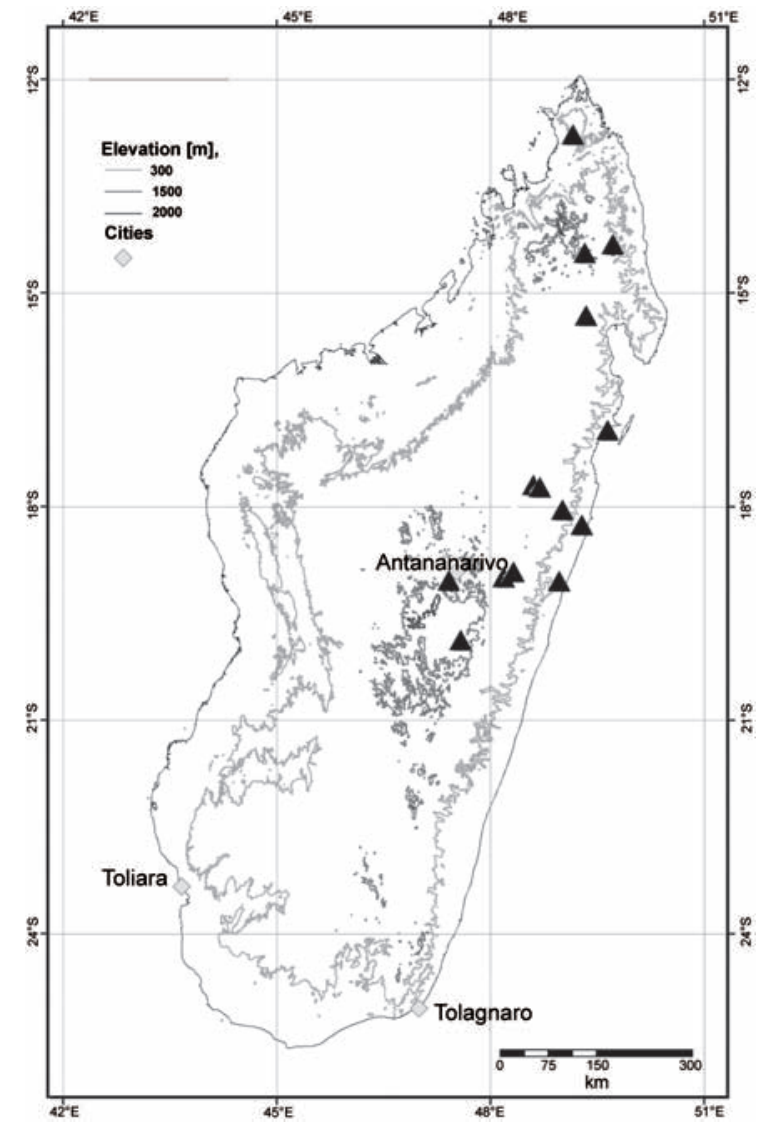

FIGURE 2. Distribution map of Zoosphaerium neptunus (Butler, 1872). Points are mapped after published records in the literature (Wesener and Wägele 2008, Wesener et al. 2010). 
examples of the curious ball insect (Spherotherium [sic] sp.), of which there are several species, at least six, in Madagascar. These insects, which are wingless and many-footed, and are called, not very elegantly, by the Malagasy Tainkintana, or 'Stardroppings', (...). In passing through the main forest in 1892, we came suddenly one day to a part of the road which was so thickly covered by such a great number of these creatures that our bearers could not avoid trampling on them. These were of a bronze-green tint and belong to a third species, and were quite three inches in length." For almost 100 years, such events were never mentioned again and all but forgotten by the scientific community, probably because of the lack of similar notions of giant pill-millipede swarms in the scientific literature.

To our own surprise, we literally stumbled upon a millipede swarm of Zoosphaerium neptunus, also called 'greeneyed monsters' by terraristic enthusiasts in the United States, in the summer of 2007 close to Andasibe (Périnet). The swarm contained small-sized individuals. Locals informed us that giant pill-millipede swarms can be regularly observed in the area.

\section{METHODOLOGY}

Night search was conducted for 15 man-hours in the natural forest at Andasibe. Swarm observations were made for two days. Weather conditions included light rain. Measurement of the length of the swarm was made with a Garmin Geko 201 GPS (accuracy $+/-8 \mathrm{~m}$ ). Counting of the actual number of individuals was tried for $100 \times 100 \mathrm{~cm}$ (unsuccessful because of too many specimens). Twenty times $10 \times 10 \mathrm{~cm}$ were randomly chosen at different points of the swarm, and all individuals were counted. Observations of the behaviour were made, separating three major activities (walking, resting, and feeding). The walking direction of individuals was noted.

At 13 randomly chosen points, 20 specimens were randomly collected and stored in $85 \%$ alcohol, altogether 260 specimens. An additional 13 deceased specimens were collected out of puddles. Three characteristics, body size (width of thoracic shield), sex, and development stage (sexually mature/immature) were recorded for all 273 specimens (see Supplementary Material). Sexes were separated based on the presence of two additional leg pairs on the posterior body end (telopods) in males. Juveniles were identified as not possessing the full number of tergites (12 + anal shield) or legs (21 in females, 23 in males), while specimens were identified as immatures using the following characters: (1) Females, non-sclerotized plates of the female vulva; (2) Males, width of inner horns on posterior telopods (see also Wesener and Sierwald 2005).

\section{RESULTS}

REPORTS OF GIANT PILL-MILLIPEDE SWARMS. Discussions with co-workers, and correspondence with other scientists conducting field work on Madagascar yielded additional unpublished records of swarming behaviour. Furthermore, sorting out millipedes in a museum collection also produced further evidence for a giant pill-millipede swarm on Madagascar. Additional reports of giant pill-millipede swarms include: (1) Written report (Sibree 1915), on way from Tamatave to Antananarivo, 1892, thousands of specimens. Length '3 inch', probably $>70 \mathrm{~mm}$.

(2) Collection vial at the Muséum National d'Histoire Naturelle, Paris, France dating from 1941 (Madagascar
- R. Decary - Betampona - Réserve Naturelle N¹ - en Forêt - 28 mai 1941) contains more than 200 Zoosphaerium neptunus, a potential indication of a millipede swarm. All specimens are between 10-15 mm long and represent immatures.

(3) and (4) M. von Tschirnhaus and S. Gehring (Marojejy, 400-600 m in 2003 and 2006), photographic evidence, 'thousands of individuals'. Specimens approximately 30-40 mm long.

(5) A. Ballerio (Andasibe, 7 January 2006), photographic evidence. Specimens approximately 30-40 mm long.

(6) M. Helb in 2001, close to Andasibe, oral report (80 specimens in one square meter) with specimens (vouchers (60 $\mathrm{mm}$ long) stored at the Field Museum, FMNHINS-55880).

(7) M. Vences, near Hevirina, Makira Plateau, 23 June 2009, video evidence, photographic evidence, specimens (vouchers (30 mm long) deposited at the Zoologische Staatsammlung Munich, ZCMV 11314). A video of the swarming was stored online under: <http://www. youtube.com/watch?V=DJ1Fw4caogE $>$

(8) J. Coddington, N. Scharff, S. Larcher, C. Griswold, R. Andriamasimanana, Parc National Montagne d`Ambre, 1,100 m, coll. 29 November 1993, specimens (vouchers (11-14 mm long), 18 immature specimens, stored at the Natural History Museum of Denmark, Copenhagen, Denmark, ZMUC 00101322).

(9) J. Coddington, N. Scharff, S. Larcher, C. Griswold, R. Andriamasimanana, Marojejy Reserve, 700 m, coll. 10-17 November 1993, specimens (vouchers (10-11.5 mm long), 24 immature specimens, stored at the Natural History Museum of Denmark, Copenhagen, Denmark, ZMUC 00101323).

ANALYSIS OF THE GIANT PILL-MILLIPEDE SWARMS. With the help of voucher specimens, precise photographs or video evidence, all the records could be determined to involve a single species, Zoosphaerium neptunus. During the night search inside the forest at Andasibe, a partially degraded rainforest, no specimen of $Z$. neptunus was found. All specimens of $Z$. neptunus discovered during this study were part of the swarm (Figure 3A). The length of the swarm was 1,100 m (accuracy +/- 16 meters), while its width varied between three and approximately $10 \mathrm{~m}$. Counting or even an estimation of the number of specimens involved in the swarm was difficult because of the large differences in local densities. Many specimens were hidden in short grass. At least several ten thousand individuals participated in the swarming event. Most specimens were observed slowly walking, a few were feeding. Many dead specimens could be found along the trail. For every three specimens observed walking probably one was found dead, almost exclusively in a puddle. However, these are arbitrary numbers, since dead specimens were more likely to be seen than living specimens, which were often hidden in the grass. The bottom of the few puddles was in some cases covered with dead specimens (Figure 3B). In fact, specimens seemed to be almost oblivious to their surroundings, at least they showed no avoidance reaction to water, nor did they try to escape from it. Quite some individuals were observed walking directly into, and drowning in, a puddle. This observation can be confirmed by photographic 

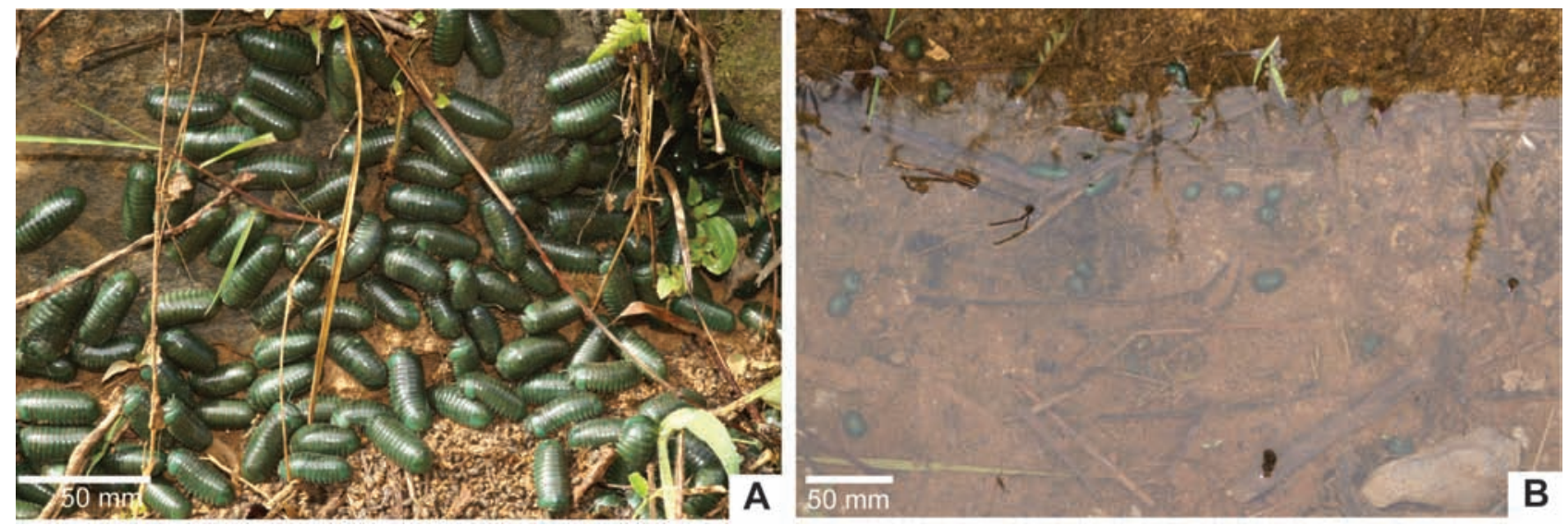

FIGURE 3. Millipede swarm of Zoosphaerium neptunus at Andasibe, Madagascar. A: Swarming individuals, B: Puddles along the swarm filled with drowned specimens.

evidence from Marojejy (Michael von Tschirnhaus and Sebastian Gehring 2006, see (3) and (4) in Results), where parts of a swarm walked into and drowned in a small river (Figure $4 \mathrm{~A}$ ).

No single specimen was observed walking 'against the current', all specimens were moving in the same direction (southeast), even when not in contact with one another. The path of the swarm was to the north barricaded by a railway track and a few meters further north by a river. Only very few specimens were observed in direct contact with the railway. some individuals were also detected on the other side of the railway, closer to the river.

Of 273 randomly collected individuals, 105 were males, while 168 were females. The males were 8.3-14.1 mm wide (average width $10.4 \mathrm{~mm}$ ). According to the inner horns of the posterior telopods (Wesener and Sierwald 2005), all males were sexually mature. The females were 9.95-15.4 mm wide (average width $11.4 \mathrm{~mm}$ ). All females displayed non-sclerotized vulvae and were sexually immature.

\section{DISCUSSION}

The collected evidence indicates a remarkable observation: The millipede swarms of Zoosphaerium neptunus contain individu- als of similar body size, and therefore presumably development stage. Most of the swarms seem to contain small to mediumsized specimens, while the swarm observed by M. Helb contained mature individuals with $60 \mathrm{~mm}$ body length, and it appears that Sibree (1915) surveyed a swarm of fully grown specimens ( $>7$ $\mathrm{cm})$. There is one eminent difference between the swarming behaviour of $Z$. neptunus and such events observed in other millipede groups (Voigtländer 2005): Even immature individuals of $Z$. neptunus form swarms. The only other described cases of juvenile millipedes forming aggregations are restricted to the order Polydesmida. Here, juveniles of some species often remain in feeding flocks, those 'swarms' never leave the soil nor show migration tendencies (Lewis 1971).

During swarming, Zoosphaerium neptunus individuals pay little attention to their surroundings; many specimens were observed walking straight into and drowning in small puddles. Some swarms even display 'cliché lemming behaviour', in Marojejy, a large part of a swarm walked into and drowned in a small river (Figure 4A).

Since no individuals of Zoosphaerium neptunus were found in the adjacent pristine rainforest, despite intense searching and ideal 'millipede' weather (wet leaf litter, slight rain), it is unlikely
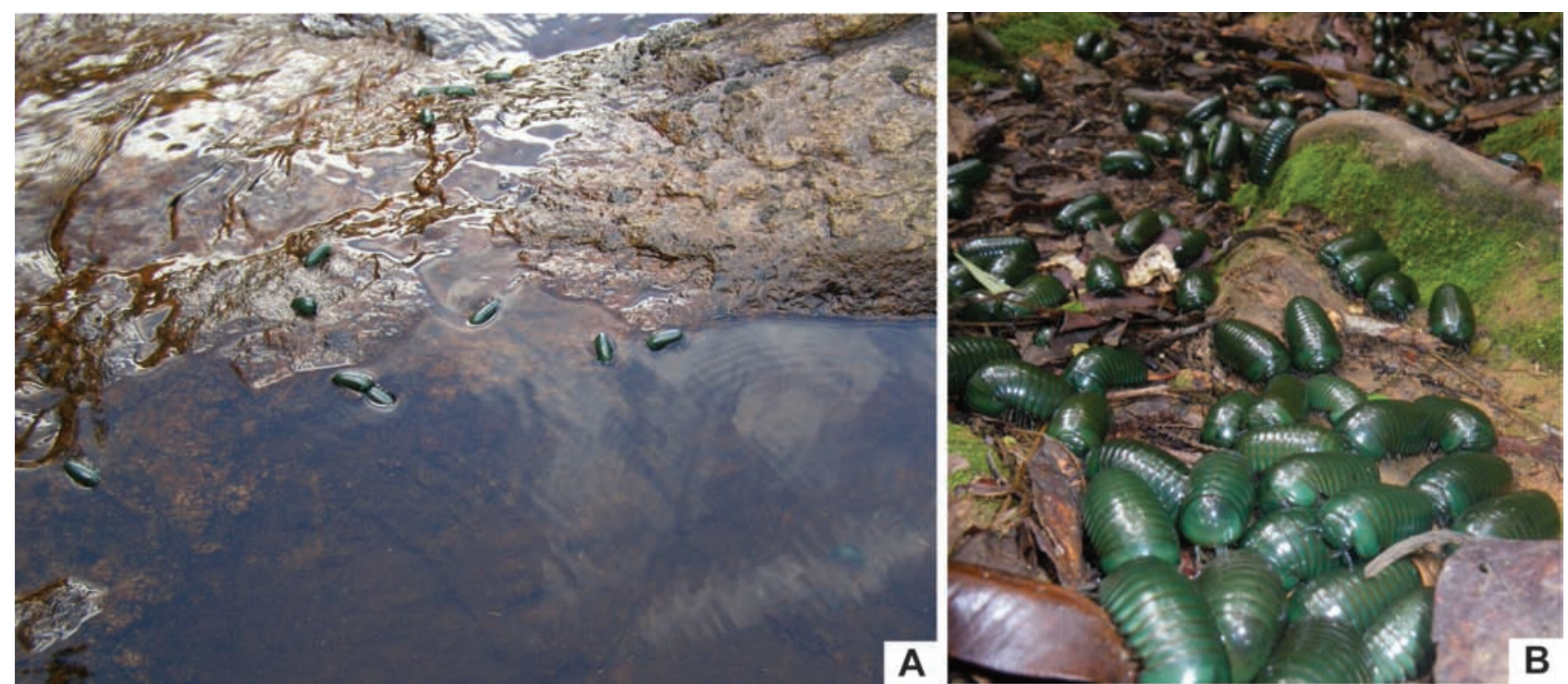

FIGURE 4. Zoosphaerium neptunus millipede swarms. A: Parts of the swarm walking into a small river at Marojejy 2006 (Photo courtesy of M. von Tschirnhaus); B: Swarm at Makira 2009, individuals circa 30-40 mm long (Photo courtesy of M. Vences). 
that the swarming behaviour of $Z$. neptunus is correlated with migrations caused by unsuitable habitat or overpopulation. Based on the 10 independent observations of $Z$. neptunus agglomerations, it can be concluded that the swarming in Z. neptunus seems to be the norm and not the exception. The reasons for such swarming behaviour in giant pill-millipedes are currently unknown, but an analysis of the individuals of the Emerald-Green giant pill-millipede involved in such swarms allows several conclusions.

(1) Giant pill-millipedes from Madagascar possess unique stridulation organs in both sexes whose function is still little understood (Wesener and Vandenspiegel 2009). Our data, however, suggests that stridulation plays no major role in the formation of such swarms in Zoosphaerium neptunus, since the stridulation ribs in females of the species are very weakly developed (Wesener and Wägele 2008).

(2) Based on an agglomeration of a fossil millipede assemblage, authors (Wilson 2006) suggested that the accumulated poisonous defence components most millipedes possess leads to an overall survival benefit of all swarm members. While this might be true for most millipede swarms (it was suggested for agglomerations of juvenile polydesmids (Lewis 1971)), it cannot be applied to giant pill-millipedes, since they are the only large-bodied millipede order known which does not possess poisonous defence fluids (Wesener and Vandenspiegel 2009).

(3) Special mating practices can be excluded as an explanation, since our data clearly show that at least all females involved in the Andasibe swarm were sexually immature.

(4) We interpret such swarms as a defense strategy against predators (although it is still unknown which animals prey on giant pill-millipedes), which increases the survival chance of each member of the millipede 'herd'. The fact that the giant pill-millipedes rely on nearly unlimited food resources (leaf litter) might add further benefits to swarming behaviour. The similar size of the individuals inside the same swarm is conspicuous. The collected evidence suggests that those swarms comprise specimens of the same generation and same area. If the individuals in one swarm have a sibling relationship remains unknown, and should be analyzed in the future with molecular methods.

\section{CONSERVATION}

Swarming behaviour is a new conservation problem for giant pill-millipedes. Because of the high number (>30\%, wesener 2009) of microendemic species, the conservation of small forest remnants should be given priority. However, millipedes like Zoosphaerium neptunus, which live in obligate swarms as part of their life cycle need a larger, non-fragmented area; such areas no longer exist in many parts of Madagascar. If large areas do not exist, the possibility is quite high that a whole swarm dies (and therefore a large amount of the whole $Z$. neptunus popula- tion in the area is gone). Swarms can come into contact with human-altered vegetation, like Eucalyptus plantations, fields or grasslands, which represents an unsuitable habitat for giant pillmillipedes (Wesener and Wägele 2007), or even roads, leading to a mass dying. The determination with which swarming individuals walked without hesitation into death traps such as puddles or even rivers are an indication of what would happen if these species came into contact with road traffic. The construction of large-scale pipelines (Rall et al. 2010) might therefore also impact the survival of this species.

Another possible threat for Zoosphaerium neptunus swarms are collections for the pet trade. There exists a large demand in Japan, Europe and North America for 'green-eyed monsters' as pets. Larger sized individuals are usually sold for Euro 15-20 in Germany. Giant pill-millipedes from Madagascar have unfortunately a very short survival time in terraria. The species is specialized on low-energy food (dead leaves), and adapted to the cool climates $\left(<20^{\circ} \mathrm{C}\right)$ of the highlands. Specimens in terraria often starve to death quickly. While for most species it would be difficult, if not impossible to collect a large percentage of a population of giant pill-millipedes in a given area because of their cryptic habits, this cannot be said about $Z$. neptunus. A single large swarm might represent the whole generation, or a significant part of it in a given area, and harvesting a complete, or a large percentage of such a swarm might irreversibly harm the survival of a Z. neptunus population in the area.

such harvesting therefore might require proper management. If a whole swarm is collected, the population of a large area could be lost at once. If only several hundred immature individuals are harvested, the impact on the population is potentially very small, since a large percentage of the swarm succumbs to obstacles like small puddles or rivers.

More studies are needed to assess the frequency of the swarming behaviour in the world's largest giant pill-millipede species, Zoosphaerium neptunus. This is something which can only be done by local researchers capable of tracking or observing swarms the whole year round.

With the help of such additional observations it might be possible to develop crucial conservation measures for the Malagasy Green Emerald giant pill-millipede Zoosphaerium neptunus, whose size makes it one of the most conspicuous mega-invertebrates of the island, and whose swarming behaviour is one of the most fascinating natural events observed in millipedes.

\section{ACKNOWLEDGEMENTS}

We thank M. von Tschirnhaus, S. Gehring, M. Helb, A. Ballerio, H. Enghoff and $M$. Vences for providing us with additional evidence of Zoosphaerium neptunus swarms on Madagascar and for kindly providing specimens, identifications, photographic and video evidence. Student assistant Uta Heidenreich assisted in conducting the measurements of the $Z$. neptunus individuals. Special thanks to Rainer Dolch (Project Mitsinjo) for providing us with invaluable help at Andasibe and Jacques Rakotondranary (Antananarivo) for logistic support. The publication is part of the Accords de Collaboration between the Universite d'Antananarivo (Département Biologie Animale and Département Anthropologie et Biologie Evolutive), and Hamburg University. The support from the late O. Ramilijaona and D. Rakotondravony (Départment de Biologie Animale, Université d'Antananarivo) is gratefully 
acknowledged. Special thanks go to the Direction des Eaux et Forêts, Antananarivo for arranging collecting and export permits. The advise of J. U. Ganzhorn (University of Hamburg) is gratefully acknowledged. Holly Walsh edited the English of the article, Nicolas Cliquennois translated the French abstract. Four anonymous reviewers improved the quality of the manuscript.

Funding for the Madagascar Field Expedition 2007 came from the German Science Foundation (DFG WA-530 37-1) and the Field Museum Collections Fund. The analysis of the data was funded by a NSF grant DEB 05-29715 to P. Sierwald, J. Bond and $\mathrm{W}$. Shear.

\section{REFERENCES}

Alagesan, P. and Muthukrishnan, J. 2006. Bioenergetics of the household pest, Xenobolus carnifex (Fabricius, 1775). Peckiana 4: 3-14.

Butler, A. G. 1872. Description of new Myriopoda of the family Glomeridae. Annals and Magazine of Natural History ser. 4, 10: 354-359, pl. 18.

Ehrnsberger, R. 2002. Massenauftreten und Wanderung des Diplopoden Ommatoiulus sabulosus in Westniedersachsen. Osnabrücker Naturwissenschaftliche Mitteilungen 28: 199-203.

Enghoff, H. and Kebapci, Ü. 2008. Calyptophyllum Iongiventre (Verhoeff, 1941) invading houses in Turkey, with the first description of the male (Diplopoda: Julida: Julidae). Journal of Natural History 42, 31: 21432150. (doi:10.1080/00222930802196055)

Lee, P. 2008. More swarming millipedes. British Myriapod \& Isopod Newsletter 16: 4

Lewis, J. G. E. 1971. The life history and ecology of three paradoxosomatid millipedes (Diplopoda: Polydesmida) in northern Nigeria. Journal of Zoology 165, 4: 431-452. (doi:10.1111/j.1469-7998.1971.tb02198.x)

Niijima, K. 2001. [A millipede outbreak (Oxidus gracilis, Koch) stopped trains]. Edaphologia 68: 43-46. In Japanese.

Rall, J. L., Andriamanamihaja, H., Ravelomanana, T., Berner, P. O. and Dickinson, S. 2010. Watercourse ecological sensitivity classification as a management framework to ameliorate pipeline construction impacts associated with the Ambatovy project. Malagasy Nature 3: 92-98.

Sharples, R. W. 1994. Theophrastus of Eresus. Sources for his life, writings, thought and influence. Vol. 5. Sources on Biology. Brill, Leiden (Netherlands).
Sibree, J. 1915. A Naturalist in Madagascar. Seeley, Service \& Co. Philadelphia, London.

Vandenspiegel, D., Golovatch, S. I. and Hamer M. L. 2002. Revision of some of the oldest species in the millipede genus Sphaerotherium Brandt, 1833 (Diplopoda, Sphaerotheriida, Sphaerotheriidae), with new synonymies. African Invertebrates 43: 143-181.

Verhoeff, K. W. 1900. Wandernde Doppelfüßer, Eisenbahnzüge hemmend. Zoologischer Anzeiger 23: 465-472.

Voigtländer, K. 2005. Mass occurrences and swarming behaviour of millipedes (Diplopoda: Julidae) in eastern Germany. Peckiana 4: 181-187.

Wesener, T. 2009. Unexplored richness: Discovery of 31 new species of Giant Pill-Millipedes endemic to Madagascar, with a special emphasis on microendemism (Diplopoda, Sphaerotheriida). Zootaxa 2097: 1-134.

Wesener, T. and Sierwald, P. 2005. New giant pill-millipede species from the littoral forest of Madagascar (Diplopoda, Sphaerotheriida, Zoosphaerium). Zootaxa 1097: 1-60.

Wesener, T. and Vandenspiegel, D. 2009. A first phylogenetic analysis of Giant Pill-Millipedes (Diplopoda: Sphaerotheriida), a new mode Gondwanan taxon, with special emphasis on island gigantism. Cladistics 25, 6: 545-573. (doi:10.1111/j.1096-0031.2009.00267.x)

Wesener, T. and Wägele, J.-W. 2007. Giant Pill-Millipedes (Diplopoda: Sphaerotheriida) in the littoral forest fragments of southeastern Madagascar. In: Biodiversity, Ecology and Conservation of Littoral Ecosystems in Southeastern Madagascar, Tolagnaro (Fort Dauphin). J. U. Ganzhorn, S. M. Goodman and M. Vincelette (eds.), pp 145-151. Smithonian Institution, Washington D.C., SI/MAB Series 11.

Wesener, T. and Wägele, J.-W. 2008. The giant pill-millipedes of Madagascar: Revision of the genus Zoosphaerium (Myriapoda, Diplopoda, Sphaerotheriida). Zoosystema 30, 1: 5-85.

Wesener, T., Bespalova, I. and Sierwald, P. 2010. Madagascarıs living giants: Discovery of five new species of endemic giant pill-millipedes from Madagascar (Diplopoda: Sphaerotheriida: Arthrosphaeridae: Zoosphaerium). African Invertebrates 51, 1: 133-161.

Wilson, H. M. 2006. Aggregation behaviour in juvenile millipedes from the Upper Carboniferous of Mazon Creek, Illinois. Palaeontology 49, 4: 733-740. (doi:10.1111/j.1475-4983.2006.00567.x) 